\title{
Why Settlement Scaling Research is a Good Fit for Archaeology
}

Michael E. Smith. Version of March 12, 2017, for pre-conference distribution

Paper for the symposium, "Settlement Scaling in Archaeology: Not Just Modern, Not Just Urban”, 82 nd annual meeting, Society for American Archaeology, Vancouver, BC.

\section{Submitted abstract:}

Although initially developed to understand contemporary urban systems, the method and theory of settlement scaling are particularly appropriate for archaeological data. The scaling framework can be seen as an outgrowth of existing archaeological research on demography and settlement patterns. Although developed independently, the "social reactor" model that explains observed patterning is, in fact, well grounded in anthropological and archaeological theory. The key process that drives change is "energized crowding," or the social interactions among individuals within the built environment. The scaling framework is general enough to apply to settlements in all types of human societies; it does not require the institutions or behaviors of the contemporary capitalist economy. This is a thoroughly empirical line of research that generates propositions that can be rigorously tested against archaeological data. Our positive findings to date contribute to a richer and broader fundamental understanding of human settlements, their generative character, and their changes over time.

\footnotetext{
At first glance settlement scaling analysis might seem far removed from the concerns of archaeologists. Could this be just another example of trying to fit the square pegs of archaeological data into the round holes of capitalist economic models? That was my reaction when I first read the work on scaling patterns in contemporary cities (Bettencourt et al. 2007; Bettencourt et al. 2010; Bettencourt and West 2010). Two things changed my mind. First, I saw that the dominant explanatory model behind the scaling regularities (Bettencourt 2013) does not rely upon modern economic institutions; it is far more broadly applicable. The model is based on the costs and benefits of social interactions of individuals as they move within the built environment of settlements. As individuals interact with one another, they achieve economic benefits. The costs and benefits to individuals are dependent on the size the settlement and on the number of residents. The beauty of this model is that the predicted numerical expressions of these micro-level actions match the observed quantitative properties of settlements. Because movement, social interactions, and built environments are characteristics of settlements throughout history, regardless of size or type of economy, the scaling model is very widely applicable.
}

The second thing that changed my mind about the relevance and applicability of settlement scaling to archaeology was the success of the initial application to archaeological data (Ortman et al. 2014, 2015). These authors showed that scaling patterns could be identified in archaeological data, and their quantitative expression matched that found for contemporary cities. Since those initial results, work by members of the "Social Reactors Project" (http://www.colorado.edu/socialreactors/) has identified the same patterns in a variety of historical and archaeological cases (Cesaretti et al. 2016; Ortman and Coffey 2015; Ortman et al. 2016). I do not think it hyperbole to point out that these are surprising findings that point to remarkable similarities among settlement systems at a very fundamental level. In this paper I 
review several ways in which settlement scaling research relates to traditional and contemporary concerns in the archaeology of ancient settlements. For a more general introduction to the concepts of the scaling approach, see Smith (2017a).

\section{Settlement Scaling Research, Settlement Patterns, and Demography}

The most obvious and direct archaeological antecedent of settlement scaling analysis is the analysis of rank-size distributions in site sizes. Empirical research first identified a power-law (exponential) distribution - known as Zipf's law - in the sizes of settlements within contemporary regions or national urban systems (Krugman 1996; Rapoport 1968; Zipf 1949). Logarithmic transformations of settlement populations produce straight line distributions when plotted against the rank of the city. Archaeologists picked up on this approach for studying site sizes from settlement surveys (Blanton 1976; Drennan and Peterson 2004; Johnson 1980; Pearson 1980; Smith 2005). Although archaeologists tended to offer a standard set of explanations - based on political dynamics and system integrity (Kowalewski 1982; Pearson 1980) — in fact these interpretations are best seen as poorly-grounded claims and speculations.

Zipfian distributions are quite widespread in the biological and physical world (Baek et al. 2011; Limpert et al. 2001), and no generally accepted explanation for their expression in human settlements exists. In settlement scaling, the relationships between settlement size and other attributes of settlements also conform to power laws, and the log-transformed values are graphed and analyzed using linear regression. But unlike the widespread Zipfian distribution, there is a clear quantitative model that explains the quantitative regularities relating the attributes of settlements to their population.

Another anthropological and archaeological antecedent of settlement scaling research is the large body of research that relates population size to other social characteristics. Early work examined the relationship between the population size of cultures or settlements, and various material expressions. One strain of research by quantitative ethnologists identified power laws in these data (Carneiro 1962, 1967; Cook and Heizer 1965, 1968).

Esther Boserup's (1965) model of the causal role of population growth in generating agricultural change initiated considerable research in the social sciences. In archaeology, this work focused on the role of population pressure in generating changes. One simplistic line of reasoning saw population pressure as the primary cause of increasing social and cultural complexity (Cohen 1977; Sanders 1979). I recall as a student hearing Kent Flannery skewer this viewpoint at an SAA meeting, noting that archaeologists like Cohen were claiming that population pressure caused everything from the rise of states to the waxy yellow buildup on your kitchen floor. While this literature led some archaeologists to reject the role of population growth in causing any social changes (Cowgill 1975; Morrison 1994), a more sophisticated line of research showed that population growth can indeed cause changes in agricultural systems, but not in political complexity (Netting 1989, 1993). Recently, Gary Feinman and others have returned to the clear and obvious correlations between group size and social institutions to explore the nature of these patterns, but now using better data and more sophisticated methods and concepts (Dubreuil 2010; Feinman 2011, 2013; Feinman and Nicholas 2016).

This very abbreviated review should suffice to show that settlement scaling analysis has a number of direct and indirect antecedents in archaeology and anthropology. What is new about 
scaling is that it has both more rigorous methods than much of the work reviewed above, and a much stronger theoretical framework - one that can predict quantitative patterns in the data with great precision.

\section{How Universal are Scaling Regularities?}

Table 1 shows the available scaling results for settlement systems before the modern ere; Table 2 lists studies from this session. The cases listed in Table 1 show an impressive regularity linking the scaling results for premodern cases with those previously identified for contemporary cases and with the values predicted by Bettencourt's (2013) model. These regularities occur in the two primary relationships identified so far. (1) Population vs. area: within a given settlement system, larger settlements are consistently denser than are small settlements; i.e., area scales in a sublinear fashion with population. Cesaretti (2016) compiles a large number of case studies from contemporary and recent peasant settlement systems that conform to the sublinear scaling of area with population. (2) population vs. wealth: larger settlements have a higher per-capital wealth level than do small settlements; i.e., wealth scales with population in a superlinear fashion.

\begin{tabular}{|c|c|c|c|}
\hline Variable & $\begin{array}{l}\text { Scaling } \\
\text { Coefficient }\end{array}$ & Examples & Citation \\
\hline \multirow[t]{8}{*}{ Area: } & $2 / 3(0.67)$ & Predicted value & Bettencourt (2013) \\
\hline & 0.57 to 0.75 & Contemporary cities & Bettencourt (2013) \\
\hline & 0.58 to 0.74 & 14th century Europe & Cesaretti et al. (2016) \\
\hline & 0.73 & Basin of Mexico, Aztec per. & Ortman et al. (2014) \\
\hline & $0.66,0.70$ & Late Horizon Andes & Ortman et al. (2016) \\
\hline & 0.66 & Mesa Verde region & Ortman \& Coffey (2015) \\
\hline & 0.67 & Middle Missouri region & Ortman \& Coffey (2015) \\
\hline & 0.62 to 0.91 & 20th century peasant systems & Cesaretti (2016) \\
\hline \multirow[t]{7}{*}{ Wealth: } & 7/6 (1.17) & Predicted value & Bettencourt (2013) \\
\hline & 1.10 to 1.22 & Contemporary cities & Bettencourt (2013) \\
\hline & 1.18 & Basin of Mexico & Ortman et al. (2015) \\
\hline & $? ?$ & 15 th century Britain & Cesaretti et al. (n.d.) \\
\hline & 1.14 & Late Horizon Andes & Ortman et al. (2016) \\
\hline & 1.17 & Mesa Verde region & Ortman \& Coffey (2015) \\
\hline & 1.19 & Middle Missouri region & Ortman \& Coffey (2015) \\
\hline \multirow[t]{2}{*}{ Plaza area: } & & Contemporary cities & (no studies) \\
\hline & $0.40,0.61$ & Mesoamerica & Ossa et al. (n.d.) \\
\hline
\end{tabular}

As the empirical results of studies by the Social Reactors Project accumulated, with each study in a sense replicating results found earlier, project members began to wonder just how far the model could be pushed. We explored increasingly divergent contexts in an attempt to "break" 
the model. We succeeded at this when we examined the campsites of mobile hunter-gatherers, from a dataset provided by Todd Whitelaw (1991, 1994). Settlement area in these systems scales with population in a superlinear fashion, meaning that large campsites are less dense than small campsites (Lobo and Ortman 2016). We are exploring these data with the help of hunter-gatherer experts, including Polly Wiessner, Curtis Marean, and Robert Kelly, in order to investigate the existence and nature of scaling regularities in these systems.

\begin{tabular}{|llll|}
\hline \multicolumn{2}{|l}{ Table 2. Scaling studies in this session } & & \\
Authors & Setting & Variables & Prediction \\
\hline Davis / Ortman & Rio Grande pueblos & Output, specialization & Superlinear \\
Hanson & Roman cities & $\left\{\begin{array}{l}\text { Area } \\
\text { Division of labor }\end{array}\right.$ & Sublinear \\
& Wendat Iroquois & Area & Sublinear \\
Birch & Medieval Europe & Economic output & Superlinear \\
Cesaretti & Coastal Peru & Area & Sublinear \\
Ortman & Output, diversity & Superlinear \\
Erny & Pre-Classical Greece & Connectivity & Superlinear \\
Hamilton / Walker & Amazon, today & $?$ & $?$ \\
\hline
\end{tabular}

We have found one other potential aberrant case: the low-density settlements of the Classic Maya. In two groups of data, we have identified superlinear scaling of area and population, a pattern that diverges from all other studied agricultural societies (and more similar to the campsites of mobile hunter-gatherers); see (Smith 2017b). The first group of data consists of settlement measurements for a complete survey in the Palenque region (Liendo Stuardo 2011), and the second is a small sample of nine major excavated Maya cities, published by Chase and Chase (2016). Before the Maya case can be properly analyzed and published, the sample of nine cities needs to be expanded (to thirty sites, if possible), and additional regional analyses need to be carried out. If the results confirm the preliminary findings, the next step is construction of a quantitative model to account for the superlinear scaling of area with population among the lowland Classic Maya. While the divergence of Maya low-density tropical cities from other urban systems may not be surprising (Fletcher 2009, 2012), the mechanisms that generate these unique patterns are far from clear.

\section{Settlement Scaling and Current Research on the Archaeology of States and Cities}

Just as settlement scaling research is grounded in a long tradition of quantitative demographic and settlement research in archaeology and other disciplines, so too is it related to a variety of current tropics in archaeology. I limit my remarks here to archaeological studies of ancient states and cities; I leave the relevance of scaling for research on hunter-gatherers and small-scale agriculturalists to others.

Additional quantitative properties of cities. Ossa, Smith and Lobo (n.d.) analyze the size of plazas in relation to settlement population in several batches of settlements in ancient Mesoamerica. They find consistent quantitative patterns that do not match any previously identified scaling pattern. While this limits the scope of possible explanations for their findings, 
the data do permit the authors to refute a common interpretation of Mesoamerican plazas - that they were designed and built in order to accommodate the entire population of each city (Inomata 2006). A potentially fruitful line of analysis would examine the scaling of the amount or size of monumental architecture, or the quantity of economic markers (such as imported goods, or craft production items) with population size. One would expect these variables to scale with population in a superlinear fashion, parallel to existing results for measures of wealth, and in fact Jack Hanson is currently working on these and related issues for ancient Roman cities (Hanson 2016).

“Urban" processes that are not limited to cities. One of the more remarkable findings of our work with the Social Reactors Project is that the empirical scaling regularities are not limited to cities. The same quantitative patterns identified for modern urban settlements are found for non-state, non-urban settlement systems (Ortman and Coffey 2015), and for the smaller hinterland settlements that are parts of urban systems (Ortman et al. 2014, 2015; Ortman et al. 2016). These results fit well with a growing body of research showing that some traits and processes once thought to be urban in nature are in fact far more widespread among human settlements.

One of the best documented examples is the neighborhood, which can be defined as "a residential zone that has considerable face-to-face interaction and is distinctive on the basis of physical and/or social characteristics" (Smith 2010:139). A study of various types of "semiurban" settlements - temporary or highly specialized settlements in which large number of people gather together - shows that neighborhoods are found in almost all such settlements (Smith et al. 2015). The implication is that neighborhoods are generated not just by fully urban settlements, but also by other contexts that draw people together, if only temporarily.

Another example of a seemingly-urban trait that is in fact prevalent in smaller and nonurban settlements is the generative role of face-to-face interaction. As implied by the labels "energized crowding" (Kostof 1991:91) and "buzz" (Storper and Venables 2004) social interactions among individuals have generative effects on society and the economy. While the number and strength of such contacts is far higher in larger settlements than in smaller ones (because the number of potential interactions increases exponentially with population size), in fact such effects are also felt in smaller settlements. For example, the negative effects of such interactions can generate scalar stress, even in small villages (Adler and Wilshusen 1990).

Urbanization before states. Archaeologists in a number of regions are beginning to turn up evidence for the presence of cities or urban centers long before the development of state institutions. One implication of this work is that it is necessary for archaeologists to separate urbanization from state formation, both conceptually and empirically (Hansen 2008; Smith 2003). Our finding that the scaling regularities are not limited to state-level societies (Ortman and Coffey 2015) lends support to this growing body of research. David Wengrow (2015) focuses on the Tripolyan mega-sites (Menotti and Korvin-Piotryovskiy 2012; Müller et al. 2016) as pre-state cities, and Takeshi Inomata and colleagues (Inomata et al. 2015) argue that ritual facilities — serving perhaps as a kind of proto-urban facility — predated state formation in the Maya lowlands. The most extensive discussion of these ideas is Justin Jennings's (2016) latest book, where he discusses several examples of early urban centers that developed and collapsed prior to the formation of state institutions in their area (Çatalhöyük, Cahokia, Harappa, and Jenne-jeno). He suggests that early cities were probably busy and chaotic places, and makes the 
perhaps unlikely claim that urbanism somehow worked against the formation of state institutions (see also Jennings and Earle 2016).

The consequences of settlement aggregation. The causes and consequences of settlement aggregation - used above as an example of a process common to urban and nonurban settlements - is currently an active area of archaeological research. The coming together of people from diverse regions or cultures to form aggregated settlements, whether villages or cities, has a common series of causal drivers and similar social implications, including energized crowding (or "buzz") and scalar stress (Adler and Wilshusen 1990; Birch 2013; Gyucha 2017; Smith 2014; Stone 1994). One result is that larger settlements - with their increased social interactions - generate higher levels of economic and social output. And this, in turn, is one of the causal forces that creates the empirical regularities of settlement scaling.

The nature of ancient economies. For reasons discussed elsewhere (Feiman 2016; Manning and Morris 2005; Smith 2004), archaeologists now recognize the extent to which the anti-market mentality of Karl Polanyi distorted the scholarly understanding of ancient economies. We now know that market economies were quite common among ancient states, but that command or redistributive economies were also prevalent in some regions such as the Andes and Dynastic Egypt (Trigger 2003). On one hand, our scaling results - particularly cases of superlinear scaling - align a number of ancient economies with more recent economic systems in consisting of networks of exchange that are not strongly embedded in political structures. But, on the other hand, we also find superlinear scaling in nonmarket economies (Ortman and Coffey 2015; Ortman et al. 2016), showing that markets are not required to achieve the network effects we document. Can we use these findings to infer that markets are not as central to economic performance today as viewed by traditional capitalist models?

\section{Settlement Scaling Research and Scientific Epistemology in Archaeology}

Settlement scaling research has another potential benefit for archaeology, in the realm of epistemology and methods. When Lewis Binford and the New Archaeologists tried to achieve "an explicitly scientific approach" for archaeology (Watson et al. 1971), they employed a faulty explanatory framework, the "covering law" approach of Carl Hempel. The failure of this approach (Flannery 1973) made it easy for the Postprocessualists to criticize "scientific" archaeology as sterile, deterministic, and inappropriate - a misguided critique that has become stale after four decades (Smith 2017c). Perhaps research in the scaling of archaeological settlement data can help archaeology move beyond entrenched and outdated epistemological positions.

The settlement scaling approach asks important questions, relies on rigorous data (i.e., careful measurement and appropriate attention to sampling), analyzed in a transparent fashion, in order to draw careful and explicitly argued conclusions. As such, this research is in line with current views in the philosophy of social science (Jarvie and Zamora-Bomilla 2011; Little 1998, 2010). In contrast to much archaeology today, where interpretation consists of speculative claims that cannot be tested (Smith 2015), we can demonstrate whether our results conform to explicit models or not.

This scientific and epistemological rigor is important, because the scaling research puts archaeology at the forefront of an exciting and transformative body of research on human 
settlements and societies. We are discovering regularities in human settlements through the ages that were undreamed of a decade ago. Our models do not require people to behave identically, or societies and economies to be organized identically. Instead, we show that the outcomes of diverse human activities - within diverse human settlements - converge on common quantitative patterns that provide new insights into human behavior and social dynamics. Without archaeology, scholars would have little idea of just how widely applicable these regularities are.

\section{References Cited}

Adler, Michael A. and Richard H. Wilshusen

1990 Large-Scale Integrative Facilities in Tribal Societies: Cross-Cultural and Southwestern United States Examples. World Archaeology 22: 133-146.

Baek, Seung Ki, Sebastian Bernhardsson, and Petter Minnhagen

2011 Zipf's law unzipped. New Journal of Physics 13 (4): 043004.

Bettencourt, Luís M. A.

2013 The Origins of Scaling in Cities. Science 340: 1438-1441.

Bettencourt, Luís M. A., José Lobo, Dirk Helbing, Christian Kühnert, and Geoffrey B. West

2007 Growth, Innovation, Scaling, and the Pace of Life in Cities. Proceedings of the National Academy of Sciences 104: 7301-7306.

Bettencourt, Luís M. A., José Lobo, Deborah Strumsky, and Geoffrey B. West

2010 Urban Scaling and its Deviations: Revealing the Structure of Wealth, Innovation and Crime Across Cities. PLoS One 5 (11): 1-9.

Bettencourt, Luís M. A. and Geoffrey B. West

2010 A Unified Theory of Urban Living. Nature 467: 912-913.

Birch, Jennifer (editor)

2013 From Prehistoric Villages to Cities: Settlement Aggregation and Community Transformation. Routledge, New York.

Blanton, Richard E.

1976 Anthropological Studies of Cities. Annual Review of Anthropology 5: 249-264.

Boserup, Ester

1965 The Conditions of Agricultural Growth: The Economics of Agrarian Change Under Population Pressure. Aldine, Chicago.

Carneiro, Robert L.

1962 Scale Analysis as an Instrument for the Study of Cultural Evolution. Southwestern Journal of Anthropology 18: 149-169.

1967 On the Relationship Between Size of Population and Complexity of Social Organization. Southwestern Journal of Anthropology 23: 234-243.

Cesaretti, Rudolf

2016 Regional Settlement Demography: Integrating Controlled Analogues into Archaeological Population Modeling. MA Paper, Department of Arizona State University.

Cesaretti, Rudolf, Luís M. A. Bettencourt, Jose Lobo, Scott Ortman, and Michael E. Smith

2016 Population-Area Relationship in Medieval European Cities. PLOS-One 11 (10): e162678. http://journals.plos.org/plosone/article?id=10.1371/journal.pone.0162678.

Chase, Arlen F and Diane Z Chase

2016 The Ancient Maya City: Anthropogenic Landscapes, Settlement Archaeology, and Caracol, Belize. Research Reports in Belizean Archaeology 13: 3-14.

Cohen, Mark Nathan 
1977 The Food Crisis in Prehistory: Overpopulation and the Origins of Agriculture. Yale University Press, New Haven.

Cook, Sherburne F. and Robert F. Heizer

1965 The Quantitative Approach to the Relation Between Population and Settlement Size. Reports, vol. 64. University of California Archaeological Research Facility, Berkeley.

1968 Relationships among Houses, Settlement Areas, and Population in Aboriginal California. In Settlement Archaeology, edited by K. C. Chang, pp. 79-116. Yale University Press, New Haven.

Cowgill, George L.

1975 On Causes and Consequences of Ancient and Modern Population Changes. American Anthropologist 77: 505-525.

Drennan, Robert D. and Christian E. Peterson

2004 Comparing Archaeological Settlement Systems with Rank-Size Graphs: A Measure of Shape and Statistical Confidence. Journal of Archaeological Science 31: 533-549.

Dubreuil, Benoît

2010 Human Evolution and the Origins of Hierarchies: The State of Nature. Cambridge University Press, New York.

Feiman, Gary M.

2016 Reframing Ancient Economies: New Models, New Questions. In Eurasia at the Dawn of History: Urbanization and Social Change, edited by Manuel Fernández-Götz and Dirk Krausse, pp. 139-149. Cambridge University Press, New York.

Feinman, Gary M.

2011 Size, Complexity, and Organizational Variation: A Comparative Approach. CrossCultural Research 45 (1): 37-58.

2013 The Emergence of Social Complexity: Why More than Population Size Matters. In Cooperation and Collective Action: Archaeological Perspectives, edited by David M. Carballo, pp. 35-56. University Press of Colorado, Boulder.

Feinman, Gary M. and Linda M. Nicholas

2016 Framing the Rise and Variability of Past Complex Societies. In Alternative Pathways to Complexity:A Collection of Essays on Architecture, Economics, Power, and CrossCultural Analysis, edited by Lane F. Fargher and Verenice Y. Heredia Espinoza, pp. 271289. University Press of Colorado, Boulder.

Flannery, Kent V.

1973 Archaeology with a Capital S. In Research and Theory in Current Archaeology, edited by Charles L. Redman, pp. 47-58. Wiley, New York.

Fletcher, Roland

2009 Low-Density, Agrarian-Based Urbanism: A Comparative View. Insights (University of Durham) 2: article 4. http://www.dur.ac.uk/ias/insights/volume2/article4/.

2012 Low-Density, Agrarian-Based Urbanism: Scale, Power and Ecology. In The Comparative Archaeology of Complex Societies, edited by Michael E. Smith, pp. 285-320. Cambridge University Press, New York.

Gyucha, Attila (editor)

2017 Coming Together: Comparative Approaches to Population Aggregation and Early Urbanization. State University of New York Press, Albany.

Hansen, Mogens Herman

2008 Analyzing Cities. In The Ancient City: New Perspectives on Urbanism in the Old and New World, edited by Joyce Marcus and Jeremy Sabloff, pp. 67-76. SAR Press, Santa Fe. Hanson, J. W. 
2016 An Urban Geography of the Roman World, 100 BC to AD 300. Roman Archaeology, vol. 18. Archaeopress, Oxford.

Inomata, Takeshi

2006 Plazas, Performers, and Spectators: Political Theaters of the Classic Maya. Current Anthropology 47: 805-842.

Inomata, Takeshi, Jessica MacLellan, Daniela Triadan, Jessica Munson, Melissa Burham, Kazuo Aoyama, Hiroo Nasu, Flory Pinzón, and Hitoshi Yonenobu

2015 Development of Sedentary Communities in the Maya Lowlands: Coexisting Mobile Groups and Public Ceremonies at Ceibal, Guatemala. Proceedings of the National Academy of Sciences 112: 4268-4273.

Jarvie, Ian and Jesús Zamora-Bomilla (editors)

2011 Sage Handbook of the Philosophy of the Social Sciences. Sage, New York.

Jennings, Justin

2016 Killing Civilization: A Reassessment of Early Urbanism and its Consequences. University of New Mexico Press, Albuquerque.

Jennings, Justin and Timothy Earle

2016 Urbanization, State Formation, and Cooperation: A Reappraisal. Current Anthropology 57 (5): 474-493.

Johnson, Gregory A.

1980 Rank-Size Convexity and System Integration: A View from Archaeology. Economic Geography 56: 234-247.

Kostof, Spiro

1991 The City Shaped: Urban Patterns and Meanings Through History. Bullfinch, Boston.

Kowalewski, Stephen A.

1982 The Evolution of Primate Regional Systems. Comparative Urban Research 9: 60-78.

Krugman, Paul

1996 Confronting the Mystery of Urban Hierarchy. Journal of the Japanese and International Economies 10 (4): 399-418.

Liendo Stuardo, Rodrigo (editor)

2011 B'aakal: Arqueología de la Región de Palenque, Chiapas, México, Temporadas 19962006. Paris Monographs in American Archaeology, 26. BAR, International Series, vol. 2203. British Archaeological Reports, Oxford.

Limpert, Eckhard, Werner A. Stahel, and Markus Abbt

2001 Log-Normal Distributions across the Sciences: Keys and Clues. Bioscience 51 (5): 341 352.

Little, Daniel

1998 Microfoundations, Method, and Causation: On the Philosophy of the Social Sciences. Transaction, New Brunswick.

2010 New Contributions to the Philosophy of History. Springer, New York.

Lobo, José and Scott G. Ortman 2016 The Scaling of Hunter-Gatherer Camp Area with Population Size. Unpublished report.

Manning, J. G. and Ian Morris (editors)

2005 The Ancient Economy: Evidence and Models. Stanford University Press, Stanford.

Menotti, Francesco and Aleksey G. Korvin-Piotryovskiy (editors)

2012 The Tripolye Culture: Giant-Settlements in Ukraine: Formation, Development and Decline. Oxbow, Oxford.

Morrison, Kathleen D. 
1994 The Intensification of Production: Archaeological Approaches. Journal of Archaeological Method and Theory 1: 111-159.

Müller, Johannes, Knut Rassmann, and Mykhailo Videiko (editors)

2016 Trypillia Mega-Sites and European Prehistory, 4100-3400 BCE. Routledge, New York. Netting, Robert McC.

1989 Smallholders, Householders, Freeholders: Why the Family Farm Works Well Worldwide. In The Household Economy: Reconsidering the Domestic Mode of Production, edited by Richard R. Wilk, pp. 221-244. Westview Press, Boulder.

1993 Smallholders, Householders: Farm Families and the Ecology of Intensive, Sustainable Agriculture. Stanford University Press, Stanford.

Ortman, Scott G., Andrew H.F. Cabaniss, Jennie O. Sturm, and Luís M. A. Bettencourt

2014 The Pre-History of Urban Scaling. PLOS-one 9 (2): e87902.

2015 Settlement Scaling and Increasing Returns in an Ancient Society. Science Advances 1 (1): e1400066.

Ortman, Scott G. and Grant D. Coffey

2015 Universal Scaling: Evidence from Village-Level Societies. SFI Working Paper, vol. 1510-044. Santa Fe Institute, Santa Fe. http://www.santafe.edu/media/workingpapers/1511-044.pdf.

Ortman, Scott G., Kaitlyn E. Davis, José Lobo, Michael E. Smith, Luis M.A. Bettencourt, and Aaron Trumbo

2016 Settlement Scaling and Economic Change in the Central Andes. Journal of Archaeological Science 73: 94-106. http://bit.ly/2aHXpGk.

Ossa, Alanna, Michael E. Smith, and José Lobo

n.d. The Size of Plazas in Mesoamerican Cities: A Quantitative Analysis and Social Interpretation. Latin American Antiquity (under review).

Pearson, Charles E.

1980 Rank-Size Distributions and the Analysis of Prehistoric Settlement Systems. Journal of Anthropological Research 36: 453-462.

Rapoport, Anatol

1968 Rank-size Relations. In International Encyclopedia of the Social Sciences, edited by David L. Sills, pp. 319-323. 2nd ed, vol. 13. Macmillan, New York.

Sanders, William T.

1979 The Jolly Green Giant in Tenth Century Yucatan, or Fact and Fancy in Classic Maya Agriculture (review of Pre-Hispanic Maya Agriculture, ed. Harrison and Turner). Reviews in Anthropology 6: 493-506.

Smith, Michael E.

2004 The Archaeology of Ancient State Economies. Annual Review of Anthropology 33: 73102.

2005 City Size in Late Postclassic Mesoamerica. Journal of Urban History 31: 403-434.

2010 The Archaeological Study of Neighborhoods and Districts in Ancient Cities. Journal of Anthropological Archaeology 29 (2): 137-154.

2014 Peasant Mobility, Local Migration, and Premodern Urbanization. World Archaeology 46 (4): 516-533.

2015 How Can Archaeologists Make Better Arguments? The SAA Archaeological Record 15 (4): 18-23.

2017a The Generative Role of Settlement Aggregation and Urbanization. In Coming Together: Comparative Approaches to Population Aggregation and Early Urbanization, edited by Attila Gyucha. State University of New York Press, Albany. 
2017b Maya Scaling Mini Report. Unpublished report.

2017c Social Science and Archaeological Inquiry. Antiquity (in press). Preprint:

https://osf.io/preprints/socarxiv/8xwsk.

Smith, Michael E., Ashley Engquist, Cinthia Carvajal, Katrina Johnston, Amanda Young, Monica Algara, Yui Kuznetsov, and Bridgette Gilliland

2015 Neighborhood Formation in Semi-Urban Settlements. Journal of Urbanism 8 (2): 173 198.

Smith, Monica L.

2003 Introduction: The Social Construction of Ancient Cities. In The Social Construction of Ancient Cities, edited by Monica L. Smith, pp. 1-36. Smithsonian Institution Press, Washington, DC.

Stone, Tammy

1994 The Process of Aggregation in the Zuni Region: Reasons and Implications. In Exploring Social, Political and Economic Organization in the Zuni Region, edited by Todd L. Howell and Tammy Stone, pp. 9-23. Anthropological Research Papers, vol. 46. Arizona State University, Tempe.

Storper, Michael and Anthony J. Venables

2004 Buzz: Face-to-Face Contact and the Urban Economy. Journal of Economic Geography 4 (4): 351-370.

Trigger, Bruce G.

2003 Understanding Early Civilizations: A Comparative Study. Cambridge University Press, New York.

Watson, Patty Jo, Steven A. LeBlanc, and Charles L. Redman

1971 Explanation in Archaeology: An Explicitly Scientific Approach. Colombia University Press, New York.

Wengrow, David

2015 Cities before the State in Early Eurasia: Goody Lecture, 2015. Max Planck Institute for Social Anthropology, Department 'Resilience and Transformation in Eurasia'.

Whitelaw, Todd

1991 Some Dimensions of Variability in the Social Organization of Community Space Among Foragers. In Ethnoarchaeological Approaches to Mobile Campsites: Hunter-Gatherer and Pastoralist Case Studies, edited by Clive Gamble and B. Boismer, pp. 139-188. Prehistory Press, Ann Arbor.

1994 Order without Architecture: Fundtional, Social and symbolic Dimensions in HunterGatherer Settlement Organization. In Architecture and Order: Approaches to Social Space, edited by Michael Parker Pearson and Colin Richards, pp. 217-243. Routledge, New York.

Zipf, George Kingsley

1949 Human Behavior and the Principle of Least Effort: An Introduction to Human Ecology. Addison-Wesley, Cambridge, MA. 